\title{
Adaptability and Phenotypic Stability of the Sugarcane RB Genotype by the AMMI Method
}

\author{
Talyta Amaral Magalhães ${ }^{1}$, Gheysa Coelho Silva ${ }^{3}$, Paulo Machado Rocha ${ }^{2}$, José Wilson da Silva ${ }^{3}$, \\ Antonio Francisco de Mendonça Júnior ${ }^{3} \&$ Francisco José de Oliveira ${ }^{3}$ \\ ${ }^{1}$ Postgraduate in Plant Genetic Improvement, Rural Federal University of Pernambuco, Recife, PE, Brazil \\ ${ }^{2}$ Sugarcane Experimental Station of Carpina, Rural Federal University of Pernambuco, Recife, PE, Brazil \\ ${ }^{3}$ Agronomy Department, Rural Federal University of Pernambuco, Recife, PE, Brazil \\ Correspondence: Antonio Francisco de Mendonça Júnior, Agronomy Department, Rural Federal University of \\ Pernambuco, Rua Dom Manuel de Medeiros, s/n, Dois Irmãos, CEP: 52171-900, Recife, PE, Brazil. Tel: \\ 55-(84)-999-033-993. E-mail: agromendoncajr@yahoo.com.br
}

Received: April 26, 2018

doi:10.5539/jas.v10n9p484
Accepted: July 1, $2018 \quad$ Online Published: August 15, 2018

URL: https://doi.org/10.5539/jas.v10n9p484

\begin{abstract}
The objective of this work is to evaluate the adaptability and phenotypic stability of the RB sugarcane genotype using the AMMI method. The experiments were performed in five production units in the state of Pernambuco, in cultivars of sugarcane soca and ressoca, using 14 RB sugarcane genotypes-11 RB clones of series 2004 and three cultivars as controls. Each combination of production unit $\times$ cutting was considered as environment, for a total of 13 environments. The experimental design was with random blocks, and four repetitions. We estimated the parameters tons of sugarcane per hectare (TCH) and tons of pol per hectare (TPH). The genotype G12 displayed general adaptability, phenotypic stability and high productivity for the two parameters. The genotypes G10, G13 and G14 had the highest yield, largest contribution of G×E, indicating specific adaptability. The environments A12 and A13, in Primavera, are recommended for preliminary selection trials.
\end{abstract}

Keywords: interaction genotype $\times$ environment, plant improvement, Saccharum spp.

\section{Introduction}

Brazil has been the world's largest producer of sugarcane for the last 30 years (FAO, 2015). The production of sugarcane anticipated for the 2017/2018 season is 647.6 million tons of cane, 38.7 million tons of sugar and 26.45 billion liters of ethanol (CONAB, 2017). Such results are mainly due to the genetic improvement of the species and the identification of genotypes with better productivity, high quality and adapted to the diverse edaphoclimatic conditions (Silva et al., 2011).

For cultivar guidance, it is necessary to perform competition trials in diverse environments and evaluate the magnitude of the genotype $\times$ environment interaction $(\mathrm{G} \times \mathrm{E})$. The influence of the interaction $(\mathrm{G} \times \mathrm{E})$ on the performance of the genotypes is of utmost importance, knowing that each genotype has an inherent capacity to respond to environment to environment changes (Pinto et al., 2011). This phenomenon represents a barrier to selection and to cultivar guidance (Andrade et al., 2013). In order to minimize such effects, breeders have to provide guidance for cultivars with large adaptability and good stability — or regional guidance - since positive interaction associated with environmental predictability represents an opportunity for commercial use (Vasconcelos, Reis, Cruz, Sediyama, \& Scapim, 2010).

Adaptability is the capacity of the genotype to respond positively to the improvement of the environment, and stability is the capacity to maintain the expected performance with environment changes (Cruz, Carneiro, \& Regazzi, 2014). The quality of the cultivars is the result of scientific knowledge accumulating over the years, mainly through competition work, and of statistical methodology used for analysis, which allows to optimally allocate genotypes to various environments (Pereira et al., 2009).

In litterature are found various statistical models suited for analyzing the adaptability and phenotypic stability. The most common are based on variance analysis, non-parametric statistics, simple linear regression analysis, mixed models and multivariate analysis (Silveira et al., 2012). The AMMI model (Additive Main Effects and Multiplicative Interaction Analysis), combines the univariate and multivariate methods, considering the main 
genotype and environment effects as additive components and the effect of the interaction as multiplicative (Silva et al., 2011). It uses variance analysis and the deconvolution of individual values, in a unified way to evaluate trials of multiple yield (Silveira et al., 2013).

This method allows to identify high-yield and largely-adapted genotypes; to realize agronomic zoning; to select test locations; to explore the positive effects of the interaction; to eliminate the noise of the interaction and present the results of the analysis in a unique biplot graphic providing easy interpretation (Duarte \& Vencovsky, 1999). There are countless literatures on adapatability and stability using the AMMI model: Guerra et al. (2009), Silva et al. (2011), Silveira et al. (2012), Souza, Bastos, Anunciação Filho, Dutra Filho, and Machado (2012), Verissimo, Silva, Aíres, Daros, and Panziera (2012), Andrade et al. (2013), Fernandes Júnior et al. (2013), Silveira et al. (2013), Dultra Filho, Júnior, and Simões Neto (2015), Antunes, Schöffel, Silva, Eicholz, and Harter (2016).

The objective of this work is to evaluate the adaptability and phenotypic stability of sugarcane RB genotypes using the AMMI (Additive Main Effects and Multiplicative Interaction Analysis) method.

\section{Material and Methods}

Fourteen sugarcane genotypes, 11 RB clones of series 2004 (G1 to G11) and three cultivars (G12 to G14) RB863129, RB867515 and BR92579 as controls. The experiments were performed in five production units in Zona da Mata de Pernambuco, with cane plantings soca (ratoon cane $-1^{\text {st }}$ season) and ressoca (ratoon cane- $2^{\text {nd }}$ season). Each combination production unit/cutting was considered as an environment, totalling 13 environments (Table 1). Phenotypic data of production seasons 2010/2011, 2011/2012 and 2012/2013 were analyzed, derived from evaluation experiments of sugarcane clones planted by Estação Experimental de Cana-de-açúcar do Carpina (EECAC), performed by Rede Interuniversitária para o Desenvolvimento do Setor Sucroenergético (Ridesa), and made available by the Programa de Melhoramento Genético da Cana-de-açúcar (PMGCA) of Universidade Federal Rural de Pernambuco (UFRPE).

Table 1. List of the 13 environments where the 14 sugarcane genotypes were tested

\begin{tabular}{llllll}
\hline ID $^{\mathbf{2}}$ & Municípality $^{\mathbf{1}}$ & Geographic Coordinates & Production Unit $^{\mathbf{3}}$ & Season & Cycle (cutting) $^{\circ}$ \\
\hline A1 & Rio Formoso & $08^{\circ} 39^{\prime} 49^{\prime \prime} \mathrm{S} ; 35^{\circ} 09^{\prime} 31^{\prime \prime} \mathrm{W}$ & Cucaú & $2010 / 2011$ & Plant \\
A2 & Rio Formoso & $08^{\circ} 39^{\prime} 49^{\prime \prime} \mathrm{S} ; 35^{\circ} 09^{\prime} 31^{\prime \prime} \mathrm{W}$ & Cucaú & $2011 / 2012$ & Soca \\
A3 & Rio Formoso & $08^{\circ} 39^{\prime} 49 " \mathrm{~S} ; 35^{\circ} 09^{\prime} 31^{\prime \prime} \mathrm{W}$ & Cucaú & $2012 / 2013$ & Ressoca \\
A4 & Camutanga & $0^{\circ} 25^{\prime} 37^{\prime \prime} \mathrm{S} ; 35^{\circ} 14^{\prime} 56^{\prime \prime} \mathrm{W}$ & Central Olho D'água & $2010 / 2011$ & Plant \\
A5 & Camutanga & $07^{\circ} 25^{\prime} 37^{\prime \prime} \mathrm{S} ; 35^{\circ} 14^{\prime} 56^{\prime \prime} \mathrm{W}$ & Central Olho D'água & $2011 / 2012$ & Soca \\
A6 & Camutanga & $07^{\circ} 25^{\prime} 37^{\prime \prime} \mathrm{S} ; 35^{\circ} 14^{\prime} 56^{\prime \prime} \mathrm{W}$ & Central Olho D'água & $2012 / 2013$ & Ressoca \\
\hline
\end{tabular}

The experiments were designed with completely randomized blocks, with four repetitions. The experimental plot was composed of five rows of 8 meters length, 1 meter wide, for a total area of $40 \mathrm{~m}^{2}$.

Planting occured in July 2010, using the standard planting system, with hand distribution of cane seeds, with three buds, along the grooves, at a depth of 30 to $40 \mathrm{~cm}$, for a total of 18 buds $^{-1}$. The management of weed control, pests and diseases was performed following recommendations for cane cultivation, and fertilizer added according to the soil chemical analysis in each location. The harvest of cane-plants was done at 15 months, first-ratoon and second-ratoon at 12 months, respectively. The evaluated parameters were tons of cane per hectare (TCH), calculated by transforming the total weight of the stalks in the plots into tons per hectare, and tons of pol per hectare (TPH) obtained by multiplying TCH by the apparent saccharose percentage (PC), the latter estimated by the sampling of 10 canes per plot, as described by Fernandes (2003).

Individual variance analysis for each location was done according to the model $Y_{i j}=\mu+G_{i}+B_{j}+\varepsilon_{i j}$, where, $Y_{i j}$ is the observed value of the $\mathrm{i}$-th genotype in the $\mathrm{j}$-th block; $\mu$ is the general mean of the experiment; $\mathrm{G}_{\mathrm{i}}$ is the effect of the $\mathrm{i}$-th genotype; $\mathrm{B}_{\mathrm{j}}$ is the effect of the $\mathrm{j}$-th block and $\varepsilon_{\mathrm{ij}}$ is the random error associated to the observation $Y_{\mathrm{ij}}$. Right after that, the global analysis was performed considering the effect of the genotype as fixed and the environment as random, following the model $Y_{i j k}=\mu+G_{i}+A_{j}+G_{i j}+\varepsilon_{i j k}$, where, $Y_{i j k}$ is the observed value of the $\mathrm{k}$-th block for the $\mathrm{i}$-th genotype in the $\mathrm{j}$-th environment; $\mathrm{GA}_{\mathrm{ij}}$ is the effect of the interaction of the $\mathrm{i}$-th genotype with the $\mathrm{j}$-th environment and $\varepsilon_{\mathrm{ijk}}$ is the random error associated to the observation $\mathrm{Y}_{\mathrm{ijk}}$.

According to Pimentel (2000), when the ratio between the largest and smallest square residual mean (QMr) is lower than seven, these are homogenous. Nonetheless, due to the lack of homogeneity, we adjusted the freedom 
degrees of the mean error and of the interaction $(\mathrm{G} \times \mathrm{E})$ according to the method of Cochran (1954). The significant effect of the $\mathrm{G} \times \mathrm{E}$ interaction indicated by the $\mathrm{F}$ test in the global variance analysis revealed a differential performance of the genotypes in relation to environment variation.

The adaptability and phenotypic stability was estimated with the AMMI model (additive main effects and multiplicative interaction analysis). According to the model described by Duarte and Vencovsky (1999): $\gamma_{\mathrm{ij}}=\mu+\mathrm{g}_{\mathrm{i}}+\mathrm{a}_{\mathrm{j}}+\sum_{\mathrm{k}=1}^{\mathrm{n}} \lambda_{\mathrm{k}} \gamma_{\mathrm{ik}} \alpha_{\mathrm{jk}}+\rho_{\mathrm{ij}}+\varepsilon_{\mathrm{ij}}$, where, $\mathrm{Y}_{\mathrm{ij}}$ is the mean response of genotype $\mathrm{i}$ in the environment $\mathrm{j}$; $\mu$ is the general mean; $g_{i}$ is the fixed effect of genotype $i$; $a_{j}$ is the random effect of environment $j$. The interaction is modeled by parameters: $\lambda_{k}$ is the singular value of the $k$-th principal component of the interaction (IPCA); $y_{j k}$ is the singular value of the $\mathrm{j}$-th environment in the k-th IPCA; $\alpha_{\mathrm{ik}}$ is the singular value of the $\mathrm{i}$-th genotype in the $\mathrm{k}$-th IPCA; $\rho_{\mathrm{ij}}$ is the residue of the $\mathrm{G} \times \mathrm{E}$ interaction, the AMMI residue (noise present in the data); $\varepsilon_{\mathrm{ij}}$ is the mean experimental error; $\mathrm{k}$ is the index which refers to the principal axes of the principal components evaluation (ACP) applied to the matrix of the interaction $(\mathrm{G} \times \mathrm{E})$; $\mathrm{n}$ is the number of axes or principal components selected for describing the pattern of the interaction.

The AMMI analysis generates a family of models AMMI0, AMMI1, AMMIF in accordance with the number of axes used, however, a few first terms are sufficient to explain the interaction (Duarte \& Vencovsky, 1999). The sum of the squares of the interaction $\left(\mathrm{SQ}_{\mathrm{G} \times \mathrm{A}}\right)$ was decomposed into eleven (IPCA), however, the models AMMI1 and AMM2, were preferred for the interpretation and visualization of the results. The interpretation of the biplot graphic was performed according to Duarte and Vencovsky (1999), the points closest to the zero axis (AMMI1), or close to the origin (AMMI2) were classified as the more stable genotypes and environments, which less contributed to the interaction; the evaluation of the high productivity was based on the means of the principal effects, present in the AMMI1 biplot; for this same analysis in the biplot AMMI2, it was necessary to do the ranking of the genotypes based on the first graphic.

The variance analysis on adaptability and phenotypic stability was performed using the software GENES (Cruz, 2013).

\section{Results and Discussion}

The global variance analysis revealed highly significant differences $(\mathrm{P} \leq 0.01)$, according to the $\mathrm{F}$ test, between the genotypes $(\mathrm{G})$, environments $(\mathrm{E})$ and the interaction $\mathrm{G} \times \mathrm{E}$, for tons of sugarcane per hectare $(\mathrm{TCH})$ and tons of pol per hectare (TPH) (Table 2). The magnitude of the variation for environments was higher than from other sources, which indicates that those were the most relevant in on tributing to the variation in productivity. Mattos, Oliveira, Bespalhok Filho, Daros, and Veríssimo (2013) reported that in multi-environmental trials, the environments explain the largest proportion of the variation. The significant interaction $G \times E$ revealed differences in the genotypes performance in response to changes in environment, justifying the use of the adaptability and stability analysis. Veríssimo, Silva, Aíres, Daros, and Panziera (2012) emphasized the importance of studying in detail the interaction for it to be controlled or used positively.

Table 2. Summary of the variance analysis for tons of sugarcane per hectare (TCH) and tons of pol per hectare (TPH) of 14 sugarcane genotypes, tested in 13 environments in the sugarcane area of Pernambuco, with indication of the original $\mathrm{G} \times \mathrm{E}$ interaction according to AMMI model, 2017

\begin{tabular}{|c|c|c|c|c|c|c|c|c|}
\hline \multirow{2}{*}{ Source of Variation } & \multirow{2}{*}{ GL } & \multicolumn{2}{|c|}{ TCH } & \multirow{2}{*}{$\operatorname{Pr}>\mathbf{F}$} & \multirow{2}{*}{ GL } & \multicolumn{2}{|c|}{ TPH } & \multirow{2}{*}{$\operatorname{Pr}>\mathbf{F}$} \\
\hline & & $\mathbf{Q M}$ & $\mathbf{F}$ & & & QM & $\mathbf{F}$ & \\
\hline Genotype (G) & 13 & $3,429.460$ & 8.786 & 0.000 & 13 & 70.234 & 5.369 & 0.000 \\
\hline Environment (E) & 12 & $25,048.059$ & 116.557 & 0.000 & 12 & 542.123 & 82.768 & 0.000 \\
\hline $\mathrm{G} \times \mathrm{E}$ & 87 & 390.325 & 1.816 & 0.012 & 71 & 13.079 & 1.997 & 0.006 \\
\hline Residual & 293 & 214.899 & - & - & 237 & 6.549 & - & - \\
\hline Interaction $\mathrm{G} \times \mathrm{E}$ (means) & 156 & 54.420 & 2.343 & 0.000 & 156 & 1.488 & 2.343 & 0.000 \\
\hline IPCA1 (standard) & 24 & 104.928 & 4.517 & 0.000 & 24 & 3.502 & 5.512 & 0.000 \\
\hline Residual AMMI1 & 132 & 45.237 & 1.947 & 0.000 & 132 & 1.122 & 1.766 & 0.000 \\
\hline IPCA 2 & 22 & 100.004 & 4.305 & 0.000 & 22 & 2.798 & 4.404 & 0.000 \\
\hline Residual AMMI1 & 110 & 34.284 & 1.476 & 0.004 & 110 & 0.787 & 1.239 & 0.073 \\
\hline Standard error/r & 378 & 23.232 & - & - & 378 & 0.635 & - & - \\
\hline
\end{tabular}


The means of the variables tons of cane per hectare (TCH) and tons of pol per hectare (TPH) were $64,17 \mathrm{tha}^{-1}$ and $8,87 \mathrm{tha}^{-1}$, respectively (Table 3 ). These values are lower when compared with other reports using RB clones (Silveira et al., 2012; Fernandes Junior et al., 2013; Silveira et al., 2013; Antunes, Schöffel, Silva, Eicholz, \& Harter, 2016), nevertheless, those differ in the series of clones, environments and seasons.

The AMMI analysis recovers part of the sum of the squares of the interaction $\left(\mathrm{SQ}_{\mathrm{G} \times \mathrm{A}}\right)$, called pattern (effect of genotypes and environments) and discard the noises (Gonçalves et al., 2010). As consequence, the first axes explain the largest proportion of the systematic variation originating from the data pattern and the other IPCAs containthe non-systematic variation, the "noise" which refers to unforeseeable and uninterpretable responses (Duarte \& Vencovsky, 1999). The more IPCAs are used largest is the noise, nevertheless it reduces the prediction power of the AMMI analysis (Zobel, Wright, \& Gouch, 1988). According to Guerra et al. (2009) evaluate the interaction using the biplot AMMI2 is nevertheless acceptable.

The sum of the squares of the interaction $\left(\mathrm{SQ}_{\mathrm{G} \times \mathrm{A}}\right)$ was decomposed into eleven principal components of the interaction (ICPAs). The models AMMI1 and AMMI2, were preferred for the interpretation and visualization of the results, since these explain $55 \%$ and $62 \%$ of the accumulated variance for TCH and TPH, respectively. These values were larger than those reported by Veríssimo, Silva, Aíres, Daros, and Panziera (2012), and Antunes, Schöffel, Silva, Eicholz, and Harter (2016) and similar to values found by Guerra et al. (2009), Silveira et al. (2012), Fernandes Junior et al. (2013), Mattos, Oliveira, Bespalhok Filho, and Darosand Veríssimo (2013), and Silveira et al. (2013).

In the biplot AMMI1(A) for TCH, the genotypes G1, G8 and G12 positionned closest to the zero axis, display phenotypic stability. Nevertheless, the genotypes G10, G13 and G14 were found to be the most distant to the zero axis, indicating low predictability. Intermediate stability was observed for the genotypes G2, G3, G4, G5, G6, G7, G9 and G11, still, genotypes G6 and G11 stand out for higher than average productivity (Figure 1). In the biplot AMMI2(B) the phenotypic stability of genotypes G1 and G12 was confirmed, as well as intermediate stability for genotypes G2, G4, G7, G9 and G11 (Figure 1). Concerning phenotypic stability, the biplot AMMI1(A) for TPH confirms that genotypes G2, G4 and G12 poorly contributed to the interaction, since those which presented the largest score magnitude for the IPCA1 axis were G3, G5, G6, G9 and G14. An intermediate stability was observed for genotypes G1, G7, G8, G10, G11 and G13, an important characteristic, since these displayed good productivity. In the biplot AMMI2(B), the stability was confirmed for genotype G12, however, the intermediate stability was not confirmed for genotypes G10 and G13 (Figure 2). This positionning is an indication of their adaptative capacity in the tested environments (Duarte \& Vencovsky, 1999). 
Tabela 3. Means of tons of sugarcane per hectares (TCH) and tons of pol per hectare (TPH), predicted by the model AMMI2, of 14 sugarcane genotypes, tested in 13 environments, in the sugarcane area of Pernambuco, 2017

\begin{tabular}{|c|c|c|c|c|c|c|c|c|c|c|c|c|c|c|}
\hline \multicolumn{15}{|c|}{ Tons of sugarcane per hectare (TCH) } \\
\hline \multicolumn{15}{|c|}{ Environments } \\
\hline Genotypes & A1 & $\mathbf{A 2}$ & $\mathbf{A 3}$ & A4 & A5 & A6 & A7 & A8 & A9 & A10 & A11 & A12 & A13 & Means \\
\hline G1 & 89.11 & 57.29 & 55.02 & 69.54 & 67.02 & 26.41 & 87.90 & 61.02 & 43.94 & 98.36 & 38.96 & 78.04 & 60.44 & 64.27 \\
\hline G2 & 90.82 & 63.95 & 66.20 & 63.33 & 65.11 & 29.02 & 79.37 & 51.13 & 31.35 & 100.92 & 35.74 & 78.31 & 55.95 & 62.26 \\
\hline G3 & 62.82 & 40.81 & 45.79 & 67.44 & 59.04 & 27.12 & 72.30 & 48.77 & 37.55 & 85.71 & 32.11 & 67.84 & 55.31 & 54.69 \\
\hline G4 & 60.39 & 32.74 & 36.10 & 47.79 & 38.59 & 14.52 & 67.87 & 41.17 & 25.58 & 83.38 & 22.80 & 62.17 & 41.79 & 44.93 \\
\hline G5 & 77.66 & 52.83 & 52.52 & 71.90 & 73.87 & 21.69 & 72.08 & 48.11 & 34.32 & 83.19 & 29.51 & 65.90 & 55.84 & 56.72 \\
\hline G6 & 101.67 & 65.92 & 63.35 & 64.98 & 60.02 & 30.53 & 96.79 & 66.72 & 45.15 & 111.73 & 44.67 & 87.82 & 61.95 & 69.71 \\
\hline G7 & 91.04 & 61.10 & 58.60 & 70.82 & 69.90 & 24.51 & 82.67 & 56.20 & 38.80 & 94.53 & 35.63 & 74.78 & 59.06 & 62.96 \\
\hline G8 & 104.71 & 68.81 & 66.35 & 63.35 & 65.22 & 30.60 & 96.48 & 65.70 & 42.83 & 113.47 & 44.43 & 88.75 & 61.15 & 70.00 \\
\hline G9 & 92.15 & 60.87 & 56.16 & 68.24 & 67.98 & 17.87 & 78.59 & 51.98 & 33.71 & 89.09 & 30.36 & 69.63 & 54.98 & $\mathbf{5 9 . 3 7}$ \\
\hline G10 & 118.53 & 79.97 & 67.97 & 83.85 & 79.98 & 23.83 & 98.18 & 70.66 & 50.09 & 101.59 & 43.12 & 82.45 & 69.12 & 74.86 \\
\hline G11 & 96.51 & 65.75 & 60.21 & 81.30 & 85.60 & 25.54 & 86.72 & 61.70 & 45.84 & 93.00 & 38.63 & 75.48 & 65.22 & 67.47 \\
\hline G12 & 99.40 & 62.87 & 55.01 & 76.55 & 78.70 & 23.59 & 94.63 & 67.95 & 50.43 & 98.09 & 41.11 & 79.03 & 64.74 & 68.45 \\
\hline G13 & 91.43 & 56.73 & 52.27 & 80.66 & 79.94 & 32.78 & 101.17 & 75.52 & 61.16 & 103.74 & 48.94 & 85.13 & 70.87 & 72.39 \\
\hline G14 & 95.22 & 53.17 & 47.06 & 66.25 & 68.12 & 27.98 & 107.44 & 78.09 & 59.22 & 111.33 & 48.67 & 88.73 & 64.79 & 70.32 \\
\hline Means & $\mathbf{9 0 . 8 1}$ & $\mathbf{5 8 . 7 7}$ & $\mathbf{5 5 . 9 0}$ & 69.71 & 68.50 & 25.42 & 87.30 & 60.33 & 42.85 & 97.72 & 38.19 & 77.43 & 60.08 & 64.17 \\
\hline \multicolumn{15}{|c|}{ Tons of pol per hectare (TPH) } \\
\hline \multicolumn{15}{|c|}{ Environments } \\
\hline Genotypes & A1 & $\mathbf{A 2}$ & A3 & A4 & A5 & A6 & A7 & A8 & A9 & A10 & A11 & A12 & A13 & Means \\
\hline G1 & 11.38 & 7.84 & 7.82 & 10.08 & 9.12 & 3.78 & 11.80 & 8.57 & 5.56 & 14.00 & 4.41 & 9.93 & 8.26 & 8.73 \\
\hline G2 & 13.32 & 9.06 & 8.70 & 9.79 & 9.05 & 3.29 & 11.70 & 8.13 & 4.93 & 13.44 & 4.06 & 9.67 & 7.91 & 8.75 \\
\hline G3 & 8.23 & 5.69 & 6.14 & 9.80 & 7.13 & 3.00 & 9.96 & 7.52 & 4.77 & 12.47 & 3.51 & 8.67 & 7.50 & 7.47 \\
\hline G4 & 8.82 & 5.13 & 5.05 & 7.20 & 6.11 & 1.29 & 9.68 & 6.21 & 3.15 & 11.96 & 1.91 & 7.58 & 5.67 & 6.22 \\
\hline G5 & 11.17 & 7.90 & 8.00 & 10.35 & 12.68 & 2.86 & 9.89 & 7.30 & 4.37 & 11.74 & 3.55 & 8.66 & 7.66 & 7.99 \\
\hline G6 & 15.97 & 10.19 & 9.13 & 8.49 & 8.20 & 4.08 & 14.96 & 9.68 & 6.06 & 16.78 & 4.90 & 11.46 & 8.26 & 9.88 \\
\hline G7 & 12.85 & 8.90 & 8.68 & 10.19 & 8.50 & 3.48 & 11.52 & 8.22 & 5.10 & 13.34 & 4.21 & 9.70 & 8.13 & 8.81 \\
\hline G8 & 13.50 & 8.99 & 8.53 & 9.56 & 10.66 & 4.19 & 13.52 & 9.36 & 6.08 & 15.60 & 4.89 & 10.89 & 8.51 & 9.48 \\
\hline G9 & 12.66 & 8.83 & 8.66 & 10.07 & 9.82 & 2.27 & 9.50 & 6.72 & 3.64 & 10.95 & 3.08 & 8.22 & 7.23 & 7.84 \\
\hline G10 & 16.93 & 11.66 & 10.83 & 10.45 & 9.98 & 4.22 & 13.54 & 9.29 & 5.82 & 14.88 & 5.13 & 11.04 & 8.89 & 10.24 \\
\hline G11 & 13.23 & 9.44 & 9.30 & 10.98 & 8.67 & 3.99 & 11.74 & 8.65 & 5.57 & 13.53 & 4.73 & 10.10 & 8.71 & 9.30 \\
\hline G12 & 13.67 & 9.31 & 8.90 & 9.98 & 7.24 & 3.98 & 12.79 & 8.97 & 5.73 & 14.69 & 4.72 & 10.50 & 8.47 & 9.36 \\
\hline G13 & 11.42 & 8.44 & 8.70 & 11.84 & 12.22 & 5.55 & 13.17 & 10.26 & 7.40 & 15.66 & 6.09 & 11.49 & 9.95 & 10.14 \\
\hline G14 & 13.84 & 8.74 & 8.02 & 7.61 & 7.98 & 4.87 & 15.70 & 10.54 & 7.09 & 18.14 & 5.52 & 12.13 & 8.77 & 10.05 \\
\hline Means & 12.64 & 8.58 & 8.32 & 9.81 & 9.21 & 3.63 & 12.10 & 8.53 & 5.38 & 14.08 & 4.34 & 10.00 & 8.14 & 8.87 \\
\hline
\end{tabular}

For TCH, the two models AMMI1(A) and AMM2(B), showed an excellent performance for genotypes G1 and G12, with high stability and productivity, around and above the mean, respectively (Figure 1 and Table 3 ). The genotypes G8 and G14 had a similar productivity. However, the genotype G8 differed for the interaction in the biplots (Figure 1 and Table 3).

Concerning stability, adaptability and productivity, for the two variables, genotype G12 looked the most promising in all tested environments (Figures 1 and 2).

Genotypes G3, G4, G5 and G9 displayed the lowest yields for TCH as well as for TPH (Table 3). And, genotypes G10, G13 and G14 displayed the highest yields, these also had the higher score magnitude for the axis of the interaction (Table 3) and (Figures 1 and 2).Similar observations were reported by Fernandes Junior et al. (2013), and Antunes, Schöffel, Silva, Eicholz, and Harter (2016) when evaluating RB clones, finding high average 
values for TCH and TPH, and low stability. So, high productivity means seem to be linked to specific adaptations (Veríssimo, Silva, Aíres, Daros, \& Panziera, 2012).

Genotypes and environments closely positionnedand in the same quadrant of the biplot are positively corerelated, enabling the easy creation of agronomic zones (Silveira et al., 2013). The AMMI2(B) analysis for TCH, indicates positive interactions between the genotype G5 in the environments A4 and A5, genotypes G6 and G8 in the environments A7, A10 and A12, genotype G10 in the environments A2 and A3, and genotype G13 in the environment A9 (Figure 1). For TPH, positive interactions were observed between G8, A8 and A12; G10, Al and A2; G14, A7 and A10 (Figure 2). Guerra et al. (2009), and Mattos, Oliveira, Bespalhok Filho, Daros, and Veríssimo (2013) using AMMI analysis identified genotypes and environments with IPCA of same signal, with positive specific interactions for sugarcane.

Positive interactions with environments (seasons) and not with locations (production unit) were also described by Verissimo, Silva, Aíres, Daros, and Veríssimo (2012), and Antunes, Schöffel, Silva, Eicholz, and Harter (2016). These results are due to changes in rain, temperatures, soil conditions, occurence of pests and diseases. In this context, stable genotypes, with broad adaptation and high productivity are constantly sought by improvement programs (Hongyu, Garcia-Peña, Araújo, \& Dias, 2014). Using regionalized cultivars, utilizing the effect of the interaction to increase productivity can be very useful in stable environments, or those which present uncommon growing conditions or even extreme conditions (Silveira et al., 2013).

Negative interactions were identified by the long distance in the biplot AMMI2(B) of genotype G14 in environments A2 and A3 (Figure 1).
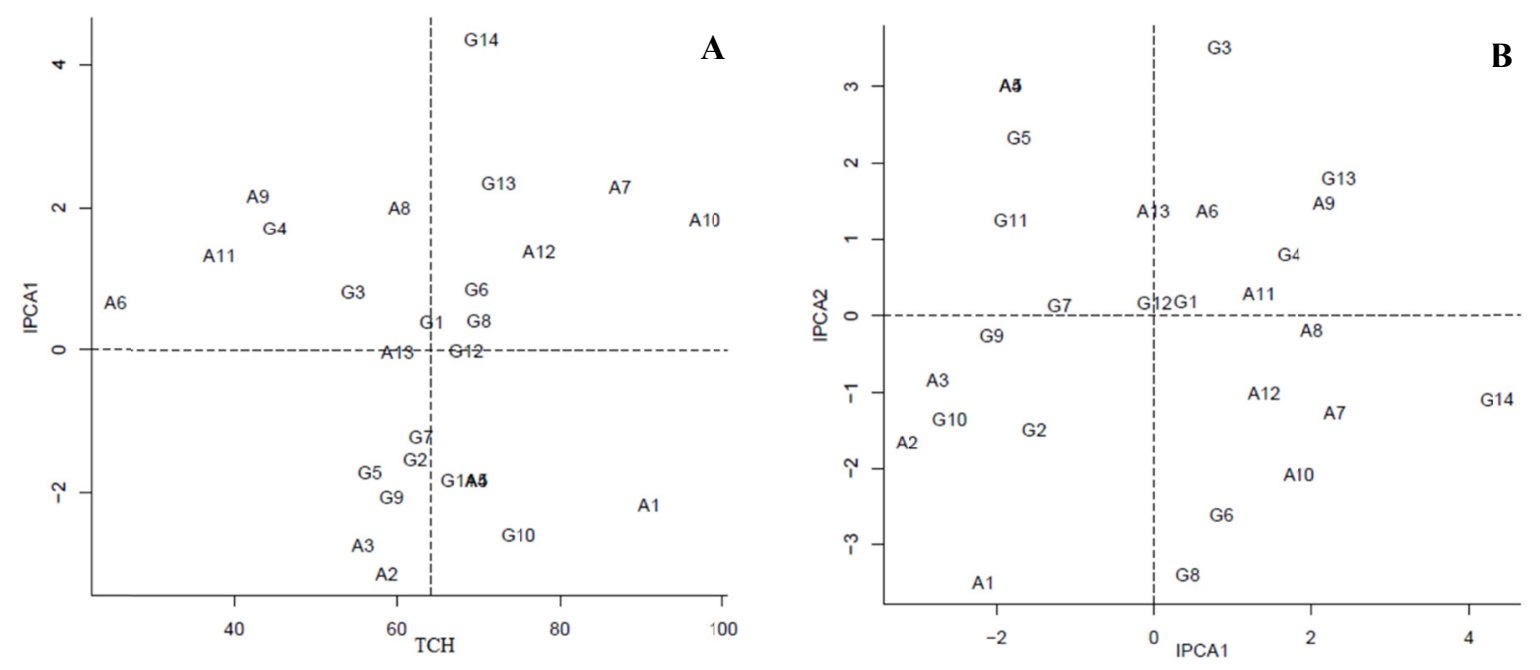

Figure 1. Biplot AMMI1(A) and AMMI2(B) for tons of sugarcane per hectare (TCH) of 14 genotypes (G), tested in 13 environments (A) in the sugarcane area of Pernambuco, 2017

And for genotypes G14 and G6 in environments A4 and A5 (Figure 2). Such negative interactions contributed for the low predictability of those. Duarte and Vencovsky (1999) point out that genotypes and environments of opposed signs must interact negatively, indicating incompatibility, an unfavorable combination. This information is fundamental for the process of selection, increasing the probability of success in recommendations. 

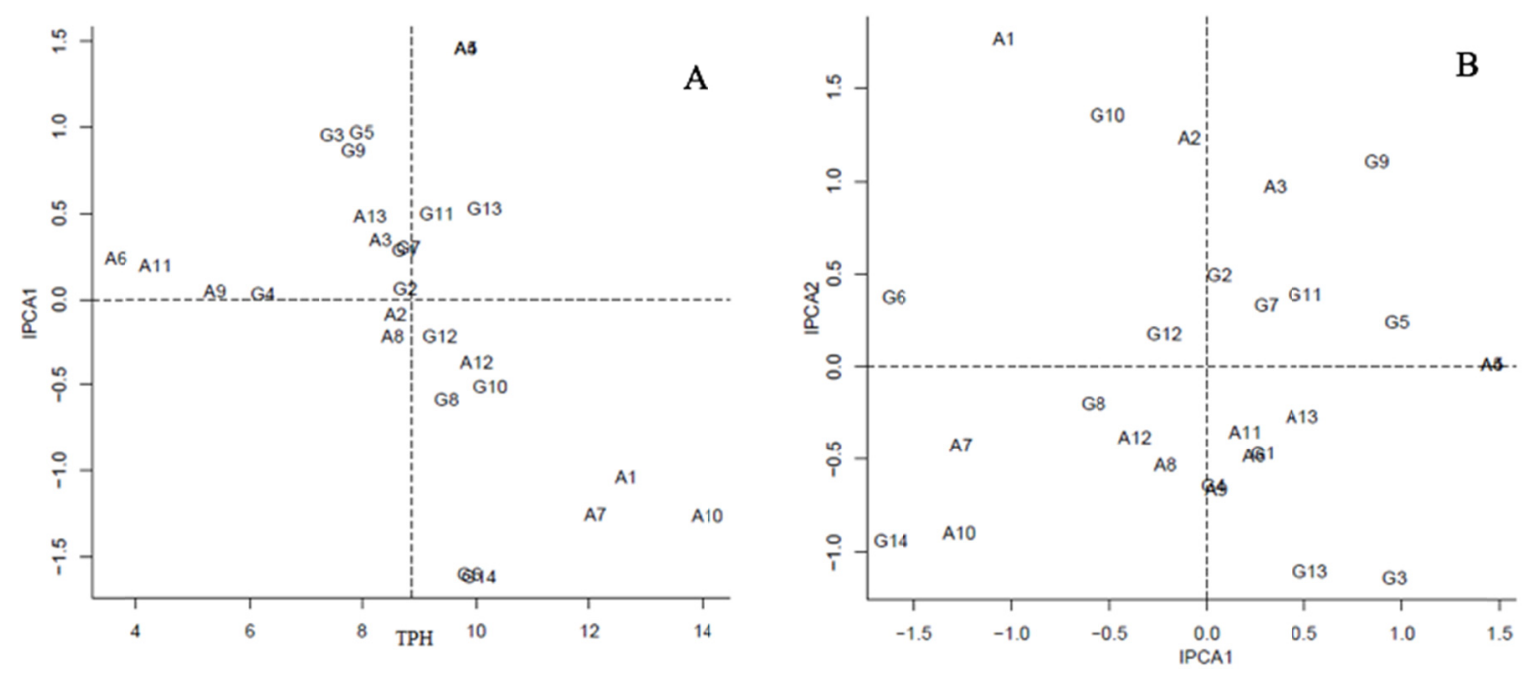

Figure 2. Biplot AMMI1(A), and AMMI2(B), for tons of pol per hectare (TPH) of 14 genotypes (G), tested in 13 environments (A) in the sugarcane area of Pernambuco, 2017

Environments A1, A4, A5, A7, A10 and A12 were classified as favorable environments since productivity above average was noted, for both TCH and TPH (Table 3). The high productivity values in these environments, are mainly the consequence of high pluviometry. The environments A6, A9 and A11 were classified as unfavorable because of low yield (Table 3). The environments which contributed the least to the interaction were A6, A8, A11, A12 and A13, since they presented lower IPCA scores, staying closer to the origin, AMMI2(B) (Figures 1 and 2). However, the modification of the interaction between the harvests (different environments) for the same location, complicates the recommendation of genotypes. Similar results were observed by Veríssimo, Silva, Aíres, Daros, and Panziera (2012) when analyzing early and medium-late genotypes of sugarcane.

For the two variables, the environments which contributed the most with the interaction were A1, A2, A4, A5, A7 and A10, since these had the highest scores AMMI2(B) (Figures 1 and 2). According to Mattos, Oliveira, Bespalhok Filho, Daros, and Veríssimo (2013) environments with highly unstable production, with strong interaction, can be used for genotype competition trials for the selection of superior plants.

The production unit in the municipality of Primavera (A12 and A13) was classified as intermediate stability for TCH and TPH. According to Duarte and Vencovsky (1999), ranking genotypes in environments which poorly contributed with the interaction, makes the classification more reliable, and this is also the most appropriate for preliminary trials. In those environments, genotypes with broad adaptability tend to stand out and can be selected with better accuracy, serving as reference for recommendations in other areas (Guerra et al., 2009).

\section{Conclusions}

Genotype G12 displayed general adaptability, phenotypic stability and high productivity for the two parameters, and can be promoted for commercial planting.

Genotypes G10, G13 and G14 displayed highest productivity, highest interaction contribution, indicating specific adaptability.

Environments A12 and A13, agricultural areas of Usina União and Indústria in Primavera-PE, are the most appropriate locations for preliminary selection trials.

\section{References}

Andrade, V. T., Rezende, J. C., Botelho, C. E., Carvalho, G. R., Gonçalves, F. M. A., \& Carvalho, A. M. (2013). Interação genótipo $\times$ ambiente em genótipos de cafeeiro Mundo Novo por modelos não lineares e multiplicativos. Bragantia, 72(4), 338-345. https://doi.org/10.1590/brag.2013.054

Antunes, W. R. A., Schöffel, E. R., Silva, D. A. S., Eicholz, E., \& Harter, A. (2016). Adaptabilidade e estabilidade fenotípica de clones de cana-de-açúcar. Pesquisa Agropecuária Brasileira, 51(2), 142-148. https://doi.org/10.1590/S0100-204X2016000200006

Cochran, W. G. (1954). Some methods for strengthening the common X2 tests. Biometrics, 10(1), 417-451. 
CONAB. (2017). Acompanhamento da safra brasileira de cana-de-açúcar. Monitoramento Agrícola-Cana-de-Açúcar/Safra/2017/18. Retrivied from http://www.conab.gov.br/OlalaCMS/uploads/ arquivos/170420140431boletimcanaportugues-1olev-17-18.pdf

Cruz, C. D. (2013). Genes-A software package for analysis in experimental statistics and quantitative genetics. Acta ScientiarumAgronomy, 35(3), 271-276. https://doi.org/10.4025/actasciagron.v35i3.21251

Cruz, C. D., Carneiro, P. C. S., \& Regazzi, A. J. (2014). Modelos biométricos aplicados ao melhoramento genético (3th ed.). Viçosa, MG: Editora UFV.

Duarte, J. B., \& Vencovsky, R. (1999). Interação genótipo × ambiente uma introdução à análise “AMMI”. Ribeirão Preto, MG: Sociedade Brasileira de Genética.

Dultra Filho, J. A., Junior, T. C., \& Simões Neto, D. E. (2015). Genetic analyses, phenotypic adaptability and stability in sugarcane genotypes for commercial cultivation in Pernambuco. Geneticsand Molecular Research, 14(4), 12102-12110. https://doi.org/10.4238/2015.October.5.23

FAO. (2017). Perspectivas agrícolas no Brasil: Desafios da agricultura brasileira 2015-2024. Retrivied from http://www.fao.org.br/download/PA20142015CB.pdf

Fernandes Júnior, A. R., Andrade, J. A. C., Santos, P. C., Hoffmann, H. P., Chapola, G. C., Carneiro, M. S., \& Cursi, D. E. (2013). Adaptabilidade e estabilidade de clones de cana-de-açúcar. Bragantia, 72(3), $208-216$. https://doi.org/10.1590/brag.2013.033

Fernandes, A. (2003). Cálculos na agroindústria da cana-de-açúcar (2nd ed.). Piracicaba-SP: EME.

Gonçalves, J. G. R., Chiorato, A. F., Morais, L. K., Perina, E. F., Farias, F. L., \& Carbonell, S. A. M. (2010). Estudo da estabilidade fenotípica de feijoeiro com grãos especiais. Ciência e Agrotecnologia, 34(4), 922-931.

Guerra, E. P., Oliveira, R. A., Daros, E. D., Zambon, J. L., Ido, O. T., \& Bespalhok Filho, J. C. (2009). Stability and adaptability of early maturing sugarcane clones by AMMI analysis. Crop Breeding and Applied Biotechnology, 9(3), 260-267.

Hongyu, K., García-Penã, M., Araújo, L. B., \& Dias, C. T. S. (2014). Statistical analysis of yield trials by AMMI analysis of genotype $\times$ environment interaction. Biometrical Letters, 51(2), 89-102. https://doi.org/10.2478/ bile-2014-0007

Mattos, P. H. C., Oliveira, R. A., Bespalhok Filho, J. C., Daros, E., \& Verissimo, M. A. A. (2013). Evaluation of sugarcane genotypes and production environments in Paraná by GGE biplot and AMMI analysis. Crop Breeding and Applied Biotechnology, 13(1), 83-90. https://doi.org/10.1590/S1984-70332013000100010

Pereira, H. S., Melo, L. C., Peloso, M. J., Faria, L. C., Costa, J. G. C., Díaz, J. L. C., ... Wendland, A. (2009). Comparação de métodos de análise de adaptabilidade e estabilidade fenotípica em feijoeiro-comum. Pesquisa Agropecuária Brasileira, 44(4), 374-383. https://doi.org/10.1590/S0100-204X2009000400007

Pimentel, G. F. (2000). Estatística experimental. Piracicaba, SP: Editora Nobel SA.

Pinto, M. F., Carvalho, G. R., Botelho, C. E., Gonçalves, F. M. A., Rezende, J. C., \& Ferrera, A. D. (2011). Eficiência na seleção de progênies de cafeeiro avaliadas em Minas Gerais. Bragantia, 71(1), $187-199$. https://doi.org/10.1590/S0006-87052012005000008

Silva, E. T., Souza, E. P., Santos, R. S., \& Barbosa, M. S. (2011). A engenharia genética aplicada no melhoramento da cana-de-açúcar: uma nova alternativa para a produção de biodiesel de segunda geração. Revista da Universidade Vale do Rio Verde, 9(2), 03-23. https://doi.org/10.5892/ruvrv.2011.92.0323

Silva, G. O., Carvalho, A. D. F., Vieira, J. V., \& Benin, G. (2011). Verificação da adaptabilidade e estabilidade de populações de cenoura pelos métodos AMMI, GGE biplot e REML/BLUP. Bragantia, 70(3), 494-501. https://doi.org/10.1590/S0006-87052011005000003

Silveira, L. C. I., Kist, V., Paula, T. O. M., Barbosa, M. H. P., Oliveira, R. A., \& Daros, E. (2012). Adaptabilidade e estabilidade fenotípica de genótipos de cana-de-açúcar no estado deMinas Gerais. Ciência Rural, 42(4), 587-593. https://doi.org/10.1590/S0103-84782012000400002

Silveira, L. C. I., Kist, V., Paula, T. O. M., Barbosa, M. H. P., Peternelli, L. A., \& Daros, E. (2013). AMMI analysis to evaluate the adaptability and phenotypic stability of sugarcane genotypes. ScientiaAgricola, 70(1), 27-32. https://doi.org/10.1590/S0103-90162013000100005 
Souza, P. H. N., Bastos, G. Q., Anunciação Filho, C. J., Dutra Filho, J. A., \& Machado, P. R. (2012). Avaliação de genótipos de cana-de-açúcar para início de safra na Microrregião Centro de Pernambuco. Revista Ceres, 59(5), 677-683. https://doi.org/10.1590/S0034-737X2012000500013

Vasconcelos, E. S., Reis, M. S., Cruz, C. D., Sediyama, T., \& Scapim, C. A. (2010). Adaptability and stability of semilate and late maturing soybean genotypes in Minas Gerais state. Acta Scientiarum. Agronomy, 32(3), 411-415. https://doi.org/10.4025/actasciagron.v32i3.8249

Verissimo, M. A. A., Silva, D. A. S., Aires, R. F., Daros, E., \& Panziera, W. (2012). Adaptabilidade e estabilidade de genótipos precoces de cana-de-açúcar no Rio Grande do Sul. Pesquisa Agropecuária Brasileira, 47(4), 561-568.

Zobel, R. W., Wright, M. J., \& Gauch, H. G. J. (1988). Statistical Analysis of a Yield Trial. Agronomy Journal, 80(3), 388-393. https://doi.org/10.2134/agronj1988.00021962008000030002x

\section{Copyrights}

Copyright for this article is retained by the author (s), with first publication rights granted to the journal.

This is an open-access article distributed under the terms and conditions of the Creative Commons Attribution license (http://creativecommons.org/licenses/by/4.0/). 